\title{
Forhidrol, a bioactive fraction of Phaleria macrocarpa (Scheff.) Boerl., increases reverse cholesterol transport pathway by down-regulation of cholesteryl ester transfer protein activity
}

\author{
Guntur Berlian, Olivia M. Tandrasasmita, Dwi A.S. Suciptan, Raymond R. Tjandrawinata \\ Section of Molecular Pharmacology, Department of Research Innovation and Invention, Dexa Laboratories of \\ Biomolecular Sciences, PT Dexa Medica, Cikarang, Indonesia
}

\begin{abstract}
Phaleria macrocarpa (Scheff.) Boerl. is one of the most popular medicinal plants in Indonesia. This plant has traditionally been used to lower cholesterol and control hypertension. This study was performed to examine the effect of Forhidrol, a bioactive fraction of
\end{abstract}

Correspondence: Raymond R. Tjandrawinata, Dexa Laboratories of Biomolecular Sciences (DLBS), PT Dexa Medica, Industri Selatan V Block PP No. 7, Jababeka Industrial Estate II, Cikarang, West Java 17550, Indonesia.

Tel: +62.21.89841901 - Fax: +62.21.89841905

E-mail: raymond@dexa-medica.com

Key words: Phaleria macrocarpa (Scheff.) Boerl.; cholesteryl ester transfer protein inhibitor; Atherosclerosis.

Contributions: GB as the first author contributed to the research study design, laboratory and experimental works, statistical data analysis and manuscript drafting. OMT contributed to the research study design, statistical analysis and manuscript drafting and review. DASS contributed to the research study design and laboratory and experimental works. RRT as the corresponding author contributed to the study design and manuscript review.

Conflict of interest: the authors declare no potential conflict of interest.

Funding: the authors received financial supports from PT Dexa Medica to conduct this study (Grant No. 070/MPC/DLBS/2015).

Acknowledgements: the authors would like to thank James Sinambela, Asep Aripin, Priska Hardadi and Ujiatmi Dwi Marlupi for preparing Forhidrol bioactive fraction, and Florensia Nailufar for the contribution in the animal study. Authors also thanked Maggy Thenawidjaja Suhartono and Isabela Anjani for their assistances in editing the manuscript.

Received for publication: 23 June 2017.

Revision received: 16 January 2018.

Accepted for publication: 4 February 2018.

CCopyright G. Berlian et al., 2018

Licensee PAGEPress, Italy

Journal of Biological Research 2018; 91:6863

doi:10.4081/jbr.2018.6863

This article is distributed under the terms of the Creative Commons Attribution Noncommercial License (by-nc 4.0) which permits any noncommercial use, distribution, and reproduction in any medium, provided the original author(s) and source are credited.
P. macrocarpa (Scheff.) Boerl., to increase reverse cholesterol transport through the down-regulation of cholesteryl ester transfer protein (CETP) activity in hepatocellular carcinoma cell lines. Measurement of target genes including liver X receptor (LXR), sterol regulatory element-binding protein 1 (SREBP-1), scavenger receptor class B type 1, low-density lipoprotein (LDL) receptor, apolipoprotein B, CYP11B1, CYP11B2, peroxisome proliferatoractivated receptor $\alpha(\operatorname{PPAR} \alpha)$, peroxisome proliferator-activated receptor $\delta(\operatorname{PPAR} \delta)$ and peroxisome proliferator-activated receptor $\gamma(\mathrm{PPAR} \gamma)$ were done using real-time polymerase chain reaction assay. Secreted CETP and apolipoprotein A-1 were analyzed using western blot. CETP activity in vitro was measured using CETP inhibitor drug screening kit and triglyceride synthesis was measured using enzyme-linked immunosorbent assay. Forhidrol was found to significantly down-regulate CETP mRNA expression, as well as total CETP and cholesteryl esters transfer activity $(\mathrm{P}<0.05)$. It specifically reduced transcriptional level of regulatory genes of CETP promoter including SREBP-1 and LXR. Forhidrol also significantly increased PPAR $\delta$ and PPAR $\alpha$ expression $(\mathrm{P}<0.05)$ and slightly repressed triglycerides synthesis. In vivo study showed elevated high-density lipoprotein (HDL) levels in rabbits after 4-week treatment of Forhidrol at a dose of $37.5 \mathrm{mg} / 1.5 \mathrm{~kg}$ body weight compared to placebo. Conversely, LDL, triglyceride and CETP activity were decreased. Forhidrol increased HDL levels by reducing CETPdependent transfer of cholesterol from HDL to LDL particles. Looking at possible side effects, Forhidrol apparently acted as a safe agent without negative effect towards blood pressure. These findings suggested that Forhidrol may be further developed as a potential antiatherogenic drug.

\section{Introduction}

Cholesteryl ester transfer protein (CETP) is a $74-\mathrm{kDa}$ hydrophobic glycoprotein which is mainly synthesized in liver and secreted to plasma. ${ }^{1-4}$ It is also produced in lymph, adipose tissue, heart, kidney and small intestine, although in a lower level. ${ }^{2,5}$ CETP is a major determinant of plasma levels of high-density lipoprotein (HDL) cholesterol in human by mediating the exchange of cholesteryl esters (CE) in HDL particles for triglycerides in lowdensity lipoprotein (LDL) and very low-density lipoprotein (VLDL) particles through reverse cholesterol transport (RCT) pathway. ${ }^{2,4,6-8}$

In epidemiological studies, subjects with CETP gene deficiency possessed higher HDL cholesterol and lower LDL cholesterol levels. ${ }^{3,9}$ Decreased HDL levels constitute a major risk factor for 
coronary heart disease and atherosclerotic cardiovascular disease, however, there was no therapy reported that substantially raise HDL levels. Inhibition of CETP has been proposed as a strategy to raise HDL levels, as human CETP deficiency resulted in markedly elevated HDL levels. It has previously been reported that elevating HDL levels by decreasing CETP mass or activity is beneficial in the inhibition of atherosclerosis progression. ${ }^{4,10-13}$

In addition to LDL protection from oxidation, ${ }^{14}$ the atheroprotective effect of HDL has also been seen on its role in RCT pathway, where excessive cholesterol in peripheral cells is distributed to the liver for secretion. ${ }^{3}$ Although there was an alternative that focused on direct administration of synthetic HDL (sHDL), ${ }^{15}$ therapies aimed to induce the production of HDL in the body may become other promising medical approaches. ${ }^{16}$

Phaleria macrocarpa (Scheff.) Boerl is a medicinal plant originated from Indonesia that is locally known as Mahkota Dewa, which has traditionally been used to lower cholesterol, as well as control hypertension and diabetes mellitus. ${ }^{17-19}$ Studies have proven its effect in the management of chronic diseases, such as hyperglycemia, dyslipidemia and kidney disorders. ${ }^{20-23}$ Earlier studies have reported that $P$. macrocarpa (Scheff.) Boerl. has the potential anti-cancer activity in breast ${ }^{24,25}$ and esophageal cancer cells, ${ }^{26}$ as well as antidiabetic, ${ }^{27,28}$ anti-cholesterol, ${ }^{21,22}$ antiatherosclerosis ${ }^{29}$ and antioxidant activities. ${ }^{27}$ Previous study exhibited potential properties of $P$. macrocarpa (Scheff.) Boerl. to improve HDL levels and its related gene. ${ }^{21}$ Other study also showed improved cholesterol profile, ${ }^{29}$ thus supporting the potential effect of $P$. macrocarpa (Scheff.) Boerl as anti-atherosclerosis. In this study, we examined the effect of Forhidrol, a bioactive fraction of P. macrocarpa (Scheff.) Boerl., on CETP mRNA expression and its activity on human hepatoblastoma cells (HepG2). Additional preliminary in vivo study in rabbit was performed to examine whether the rise in HDL observed clinically with Forhidrol treatment could be a result of decreased CETP activity.

\section{Materials and Methods}

\section{Preparation and phytochemical characterization of Forhidrol}

P. macrocarpa (Scheff.) Boerl. was collected from Central Java, Indonesia. This plant has been identified in Herbarium Bogoriense, Research Center of Biology, Indonesian Institute of Sciences with certificate No. 261/IPH.1.02/If.8/XII/2009. Dried fruits of $P$. macrocarpa (Scheff.) Boerl. were macerated with ethanol $96 \%$ at $25-50{ }^{\circ} \mathrm{C}$ for $2-6 \mathrm{~h}$, followed by filtration and evaporation. The extract was further dried in vacuum oven for 2-4 h to obtain dry material and analyzed by thin layer chromatography (TLC). The dried material was referred as Forhidrol bioactive fraction. The concentration of Forhidrol used in this experiment was based on its dry weight $(\mu \mathrm{g} / \mathrm{mL})$.

Identification of active compound in Forhidrol was carried out qualitatively using TLC method. The sample was spotted on silica gel plate and eluted with a mixture of chloroform and methanol (10:1). Observation was done under UV light at 254 and $366 \mathrm{~nm}$. Forhidrol was also characterized using fourier transform infrared (FTIR) and nuclear magnetic resonance (NMR) spectroscopy. FTIR analysis was carried out using FTIR-6100 (Jasco, Japan) at a wavelength range of $4000-700 \mathrm{~cm}^{-1}$, while NMR analysis was carried out using chloroform-D as the solvent $\left({ }^{1} \mathrm{H}\right.$ at $500 \mathrm{MHz}$ and ${ }^{13} \mathrm{C}$ at $125 \mathrm{MHz}$ ) and NMR JEOL $500 \mathrm{MHz}$ (JEOL, Japan).

\section{Cell culture and in vitro experiments}

HepG2 lines were purchased from American Type Culture Collection (ATCC, Rockville, MD). The cells were maintained in minimum essential-alpha (Gibco, CA, USA) medium supplemented with $10 \%$ fetal bovine serum (Gibco, CA, USA), $100 \mu \mathrm{g} / \mathrm{mL}$ penicillin-streptomycin (Gibco, CA, USA) and $1 \mathrm{mM}$ sodium pyruvate (Gibco, CA, USA) at temperature of $37^{\circ} \mathrm{C}$ in $5 \% \mathrm{CO}_{2}$ atmosphere. Eighty percent of confluent cells were maintained in serum-free medium for $4 \mathrm{~h}$ before treatment. The cells were then treated with $0-100 \mu \mathrm{g} / \mathrm{mL}$ Forhidrol and $30 \mu \mathrm{M}$ linoleic (Sigma, $\mathrm{MO}$, USA) or arachidonic acids (MP Biomedical, OH, USA) for $24 \mathrm{~h}$.

\section{Real-time polymerase chain reaction analysis for mRNA expression}

Total RNA was extracted using TRIzol reagent (Invitrogen, CA, USA) according to the manufacturer's protocol. The RNA concentration was quantified using NanoDrop 2000c spectrophotometer (Thermo Scientific, USA). The expressions of several genes including liver $\mathrm{X}$ receptor (LXR), sterol regulatory element-binding protein 1 (SREBP-1), scavenger receptor class B type 1 (SR-B1), LDL receptor (LDL-R), apolipoprotein B (ApoB), CYP11B1, CYP11B2, peroxisome proliferator-activated receptor $\alpha$, $\delta$ and $\gamma(\operatorname{PPAR} \alpha, \operatorname{PPAR} \delta$ and PPAR $\gamma)$, were determined using realtime polymerase chain reaction (PCR). Primers for each gene (Table 1) were synthesized by First Base Laboratories (Singapore). The PCR amplification was performed in a total volume of $25 \mu \mathrm{L}$ reaction

Table 1. Sequences of the primers used in the polymerase chain reaction measurements.

\begin{tabular}{ll} 
Gene & Sequence $\left(5^{\prime} \rightarrow 3^{\prime}\right)$ \\
CETP & Forward: GTGCTTGCCTTCTGCTACAAG \\
& Reverse: CGAGTCTTCCACTCGCTGGC \\
LXR & Forward: CGGGCTTCCACTACAATGTT \\
& Reverse: TCAGGCGGATCTGTTCTTCT \\
\hline SREBP-1 & Forward: TGCATTTCTGACACGCTTC \\
& Reverse: CCAAGCTGTACAGGCTCTCC \\
SR-B1 & Forward: CTGTGGGTGAGATCATGTGG \\
& Reverse: GCCAGAAGTCAACCTTCTC \\
\hline ApoB & Forward: TTTGCCCTCAACCTACCAAC \\
& Reverse: TGCGATCTTGTTGGCTACTG \\
LDL-R & Forward: TCTGTCGTGTGTGTTGGGAT \\
& Reverse: ACGACAAGATTGGGGAAGTG \\
\hline PPAR $\alpha$ & Forward: GCTGGTGCAGATCATCAAGA \\
& Reverse: GCCGGTTACCTACAGCTCAG \\
PPAR $\delta$ & Forward: ACTGAGTTCGCCAGGAGCAT \\
& Reverse: GCGTTGAACTTGACAGCAAA \\
\hline PPAR $\gamma$ & Forward: ACTGAGTTCGCCAAGAGCAT \\
& Reverse: GCGTTGAACTTGACAGCAAA \\
CYP11B1 & Forward: CTCTACCCTGTGGGTCTGTTTC \\
\hline CYP11B2 & Reverse: GGGTTATAGCGCTCAGGCC \\
& Forward: CTCTACCCTGTGGGTCTGTTTT \\
& Reverse: GGATTATACCGCTCAGGC \\
& Forward: ACCCACACTGTGCCCATCTA \\
& Reverse: CGGAACCGCTCATTGCC \\
\hline
\end{tabular}

CETP, cholesteryl ester transfer protein; LXR, liver X receptor; SRBP-1, sterol regulatory element-binding protein 1; SR-B1, scavenger receptor class B type 1; ApoB, apolipoprotein B; LDL-R, low-density lipoprotein receptor; PPAR $\alpha$, peroxisome proliferator-activated receptor $\alpha$; PPAR $\delta$, peroxisome proliferator-activated receptor $\delta$; PPAR $\gamma$, peroxisome proliferator-activated receptor $\gamma$. 
mixture consisting of $12.5 \mu \mathrm{L} \mathrm{iQ}^{\mathrm{TM}} \mathrm{SYBR}{ }^{\circledR}$ Green Supermix (Biorad, CA, USA), $0.8 \mu \mathrm{M}$ of each targeted primer and $0.1 \mu \mathrm{M}$ of each targeted primer and $0.1 \mu \mathrm{M}$ of each $\beta$-actin primer as the internal control. The real-time PCR was performed using Mini Opticon MJ Mini ${ }^{\mathrm{TM}}$ (Biorad, CA, USA) at optimum conditions for each primer.

\section{Western blot}

Secreted CETP and Apolipoprotein A-I (ApoA-I) proteins in the medium were analyzed using western blot (BioRad, CA, USA). The medium was concentrated up to 10 fold using filter with $10 \mathrm{kDa}-$ molecular weight cut-off membrane (Millipore, MA, USA), and measured using Bradford method. The protein was further separated by SDS-PAGE using $10 \%$ acrylamide gel at $100 \mathrm{~V}$ for $150 \mathrm{~min}$. The protein was then transferred to polyvinylidene difluoride (PVDF) membrane by blotting system at $500 \mathrm{~mA}$ for $75 \mathrm{~min}$. The blots were incubated with CETP, ApoA-I and $\beta$-actin primary as well as secondary antibodies, with dilution of $1: 500$ and 1:10000, respectively. The protein band was visualized using luminol chemiluminescence reagent and exposed to a film (FUJIFILM, Tokyo, Japan) in the dark room. Antibodies (both primary and secondary), PVDF membranes and luminol reagent were purchased from Santa Cruz Biotechnology, Inc. (Santa Cruz, CA, USA).

\section{Cholesteryl ester transfer protein activity assay}

Effect of Forhidrol on in vitro CETP activity was assayed using CETP inhibitor drug screening kit (BioVision, CA, USA) according to the manufacturer's protocol. The results were evaluated based on the fluorescence intensity of neutral lipid transferred to the acceptor molecule mediated by CETP. The concentrations of Forhidrol used in this experiment were ranged from $0-100 \mu \mathrm{g} / \mathrm{mL}$.

\section{Triglycerides synthesis assay in vitro}

Effect of Forhidrol on in vitro triglycerides synthesis was assayed using triglycerides synthesis enzyme-linked immunosorbent assay (ELISA) kit. (Abcam, Cambridge, UK) according to the manufacturer's protocol. Oleic acid (Sigma, MO, USA) at a concentration of $0.5 \mathrm{mM}$ was pre-treated to HepG2 cells to induce triglycerides synthesis and used as the negative control. The concentrations of Forhidrol used in this experiment were ranged from $0-100 \mu \mathrm{g} / \mathrm{mL}$.

\section{In vivo study}

Kits for the measurement of HDL, LDL, triglycerides and CETP activity levels were purchased from BioVision (CA, USA). Ten male New Zealand white rabbits $(2.3-2.5 \mathrm{~kg})$ were maintained at animal laboratory of Dexa Laboratories of Biomolecular Sciences (Cikarang, Indonesia). The animal study was conducted after research ethics approval from ethical institutional advisory committee as suggested by Association for Assessment and Accreditation of Laboratory Animal Care (AAALAC) International. The rabbits were individually housed according to AAALAC guidelines and given free access to water and fed a normal diet. Before experiment, blood plasma of each rabbit was collected for the measurement of normal baseline levels of HDL, LDL and triglyceride, as well as CETP activity. They were further divided into two groups consisting of control (placebo) and Forhidrol treatment group. Rabbits in the control group were fed a normal diet, while the treatment groups were fed the same diet supplemented with $37.5 \mathrm{mg}$ Forhidrol $/ 1.5 \mathrm{~kg}$ body weight. The level of plasma lipids and CETP activity were measured every week within 4-week treatment. All measurements were done using blood samples from 12-h fasted rabbits which were withdrawn from ear veins.

\section{Statistical analysis}

Statistical differences between test and control groups were determined by t-test analysis using the StatView package (Abacus Concepts, Inc., Barkeley, CA). Values are expressed as mean \pm standard deviation (SD) for 3 independent experiments.

\section{Results}

\section{Phytochemical characterization of Forhidrol}

Observation under UV light at 254 and $366 \mathrm{~nm}$ showed that Forhidrol contains a group of compounds with $\mathrm{Rf}$ value between $0.16-0.35$ by which it conferred its specific biological activity. FTIR analysis at a wavelength range of 4000-700 $\mathrm{cm}^{-1}$ showed a functional group of $\mathrm{OH}$, aliphatic and carbonyl $(\mathrm{C}=\mathrm{O})$. Moreover, NMR analysis revealed that Forhidrol may contain unsaturated fatty acid esters (C25). This evidence concludes that Forhidrol is a multicomponent bioactive fraction containing several hydrocarbon compounds as well as fatty acids.

\section{Forhidrol decreases the expression and activity of cholesteryl ester transfer protein}

Dose response and time course studies of Forhidrol in decreasing CETP activity were evaluated in HepG2 cells. As shown in Figure 1A, mRNA levels of CETP were decreased in the presence of Forhidrol in a dose-dependent manner (Figure 1A). At the highest concentration $(100 \mu \mathrm{g} / \mathrm{mL})$, CETP mRNA level was decreased by $82 \%$. Time course study showed that Forhidrol reduced CETP mRNA level by almost $50 \%$ after $4 \mathrm{~h}$ of incubation. Within $16 \mathrm{~h}$, lower CETP expression was clearly found as the result of increasing incubation time. Although Forhidrol activity was slightly decreased after 24 and $32 \mathrm{~h}$ of incubation, overall data revealed that Forhidrol decreased CETP expression in a time-dependent manner. Moreover, inhibitory activity of Forhidrol was also found at the protein level of CETP which was revealed by western blot. CETP protein was significantly declined in the cells treated with $100 \mu \mathrm{g} / \mathrm{mL}$ Forhidrol (Figure 1C). These results indicated that Forhidrol contributed to the repression of CETP in transcription and translation levels.

We also investigated the effect of Forhidrol on CETP activity in vitro. Administration of Forhidrol resulted in a significant inhibition of CETP activity which occurred in a dose-dependent manner (Figure 1D). This finding suggests that Forhidrol also served as a CETP activity inhibitor in mediating cholesterol transport. The maximum inhibition of CETP activity by Forhidrol was $30 \%$, which was found at a concentration of $100 \mu \mathrm{g} / \mathrm{mL}$.

\section{Forhidrol regulates cholesteryl ester transfer protein transcription regulatory genes}

CETP transcription is regulated by several regulatory genes including SREBP1, LRH-1, ARP1 and LXR. In this study, the genes were investigated for their response towards Forhidrol administration. mRNA level analysis revealed that LXR and SREBP1 genes were progressively down-regulated following Forhidrol administration $(0-75 \mu \mathrm{g} / \mathrm{mL})$ (Figure 2). Forhidrol at a concentration of $75 \mu \mathrm{g} / \mathrm{mL}$ exhibited a down-regulation of LXR expression by up to $75 \%$, while higher level was observed on SREBP1 gene which exhibited $95 \%$ inhibition. In other hands, we did not find any alteration in other CETP transcriptional regulatory genes (data not shown). Based on the result, we suggested that inhibition of CETP transcription may occur due to the downregulation of LXR $\alpha$ and SREBP1. 


\section{Effect of Forhidrol on apolipoprotein A-I protein level}

The effect of Forhidrol on ApoA-I, a major protein component of HDL, was also evaluated. Our in vitro study in HepG2 cells using western blot revealed that Forhidrol slightly elevated ApoA-I protein level in a dose-dependent manner, with $30 \%$ increment of ApoA-I by the highest Forhidrol concentration $(100 \mu \mathrm{g} / \mathrm{mL}$ ) (Figure $3 \mathrm{~A})$. This result indicated that CETP inhibition might induce the cells to express more ApoA-I in order to produce new HDL particles.

Effect of Forhidrol on scavenger receptor class B type 1, low-density lipoprotein receptor, and apolipoprotein B mRNA level

The potential effect of Forhidrol towards genes related to HDL and LDL levels was further studied in order to evaluate the effect of Forhidrol in cholesterol transport pathway. As seen in Figure $3 \mathrm{~B}$, the expression of SR-B1 gene, which encodes HDL receptor, was decreased by Forhidrol treatment in a dose-dependent manner with inhibition level of up to $70 \%$ at Forhidrol concentration of $100 \mu \mathrm{g} / \mathrm{mL}$. Forhidrol also altered the expression of LDL-R by increasing its expression in a dose-dependent manner in which the optimum elevation $(200 \%)$ was observed at a concentration of 50

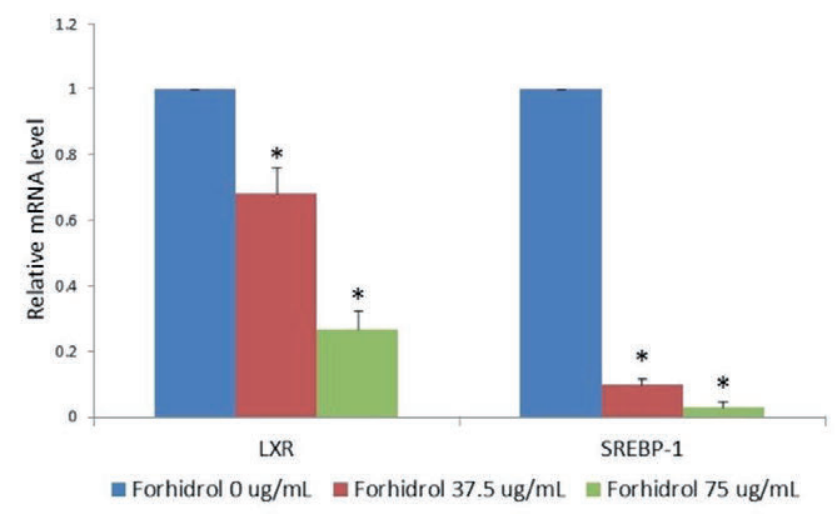

Figure 2. Forhidrol down-regulates regulatory genes of cholesteryl ester transfer protein promoter. Hepatocellular carcinoma cells were incubated with Forhidrol $(75 \mu \mathrm{g} / \mathrm{mL})$ for $24 \mathrm{~h}$ and total RNA was extracted. The mRNA levels of liver $\mathrm{X}$ receptor (LXR) $\alpha$ and sterol regulatory element-binding protein 1 (SREBP-1) were analyzed by real-time polymerase chain reaction and normalized to $\beta$-actin. Results are exp ressed as mean $\pm \mathrm{SD}$ of two independent experiments. ${ }^{*} \mathbf{P}<0.05$ indicates a significant difference compared to control.
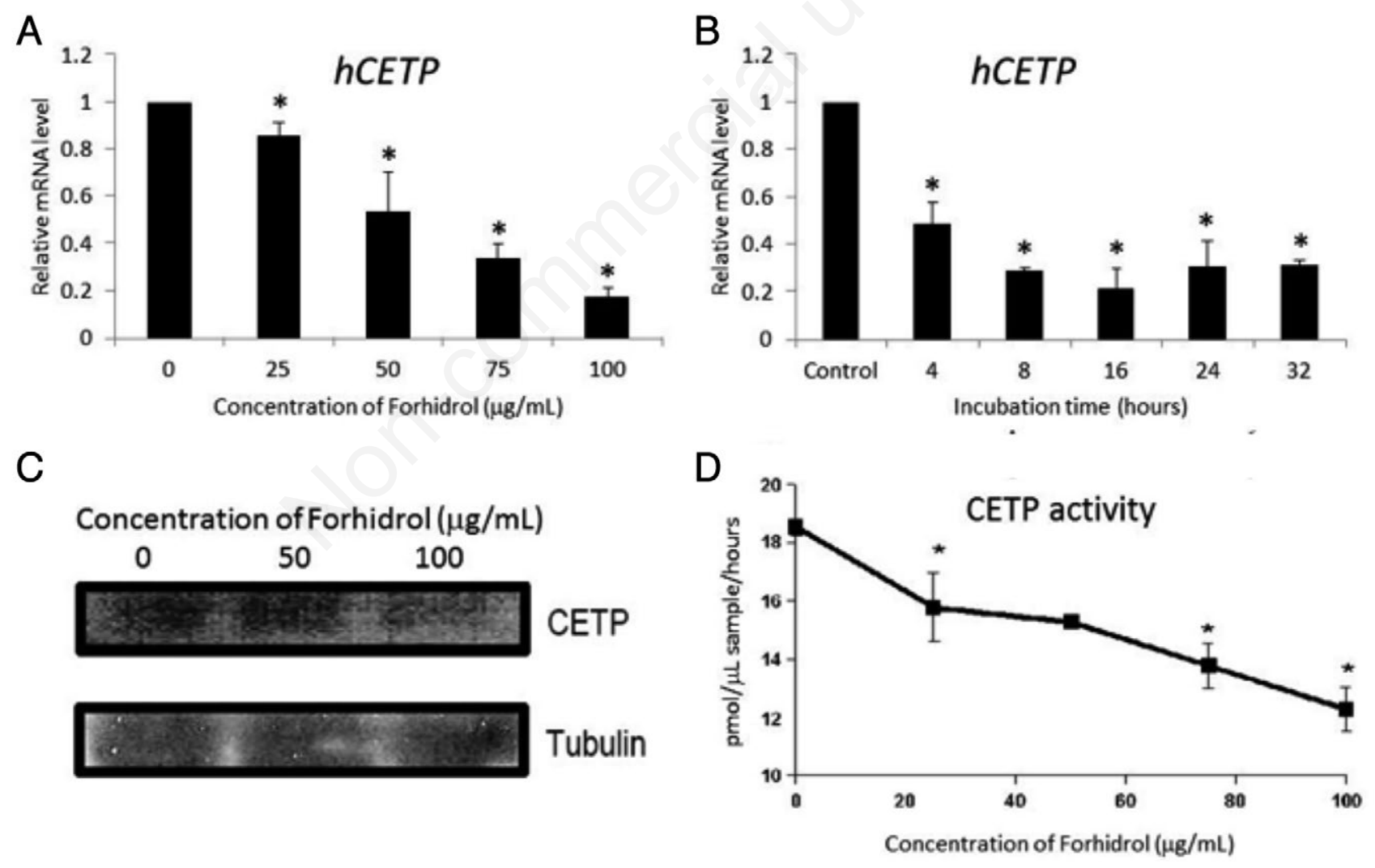

\footnotetext{
Figure 1. Forhidrol decreases cholesteryl ester transfer protein (CETP) at transcription level in dose-dependent (A) and time-dependent manner (B). Forhidrol also affects CETP expression at protein level (C), as well as CETP activity (D). For dose-response study, Hepatocellular carcinoma (HepG2) cells were treated with Forhidrol $(0-100 \mu \mathrm{g} / \mathrm{mL})$ for $24 \mathrm{~h}$ and total RNA and protein were extracted. The expression levels of CETP mRNA were analyzed by real-time polymerase chain reaction (PCR) and normalized to $\beta$-actin. CETP protein levels were analyzed by western blot method while CETP activity was analyzed using CETP inhibitor drug screening kit. For time-course study, HepG2 cells were treated with Forhidrol $(75 \mu \mathrm{g} / \mathrm{mL})$ for $4,8,16,24$ and $32 \mathrm{~h}$, then total RNA were extracted. The expression levels of CETP mRNA were analyzed by real-time PCR and normalized to $\beta$-actin. Results are expressed as mean \pm SD of two independent experiments. ${ }^{*} \mathbf{P}<0.05$ indicates a significant difference compared to control.
} 
$\mu \mathrm{g} / \mathrm{mL}$. Although LDL-R expression observed at $50 \mu \mathrm{g} / \mathrm{mL}$ was higher than that at higher Forhidrol concentration, its administration still produced a significant increment of LDL-R expression compared to that of the control. Alterations of gene expression by Forhidrol were also observed in apolipoprotein B (ApoB), which is the main component of LDL. Forhidrol conferred down-regulation of ApoB gene at mRNA level in a dosedependent manner. The down-regulation was started to be significant at a concentration $50 \mu \mathrm{g} / \mathrm{mL}$ and progressively decreased at higher concentrations.

\section{Effect of Forhidrol and polyunsaturated fatty acid} on cholesteryl ester transfer protein mRNA level

Polyunsaturated fatty acids (PUFAs), e.g. arachidonic acid (AA) and linoleic acid (LA), were used as the control for observation of CETP inhibition at mRNA level. As seen in Figure 4, we found that administration of AA and LA at a concentration of $30 \mu \mathrm{M}$ decreased the expression of CETP. Moreover, addition of Forhidrol (75 $\mu \mathrm{g} / \mathrm{mL})$ in PUFA-treated sample showed a higher decrement of CETP expression compared to PUFAs alone.

\section{Effect of Forhidrol in regulating proliferator-activated receptors expression at $\mathrm{mRNA}$ level}

mRNA level of transcription factor PPAR family was evaluated for their response towards Forhidrol administration. Compared to the control, administration of Forhidrol was able to significantly increase PPAR $\delta$ expression in a dose-dependent manner, with the highest increment of up to 4.1 folds, while significant increase of PPAR $\alpha$ expression by 3 folds only occurred at a concentration of $100 \mathrm{mg} / \mathrm{mL}$, and there was no significant effect found on PPAR $\gamma$ (Figure 5). These results indicate that Forhidrol also modulated lipoprotein metabolism by up-regulating the transcription levels of PPARs, including PPAR $\delta$ and PPAR $\alpha$.

\section{Effect of Forhidrol on triglycerides synthesis in vitro}

Triglycerides, as far as is currently known, are not directly atherogenic but represent an important biomarker of cardiovascular diseases risk due to their association with proatherogenic proteins found on all classes of the plasma lipoproteins. The effect of Forhidrol on triglycerides synthesis was evaluated. In vitro study in HepG2 cells revealed that triglyceride levels was increased by $83 \%$ after the addition of oleic acid compared to control, while Forhidrol administration was found to reduce triglycerides by up to $31 \%$ compared to oleic acid-treated group (Figure 6).

\section{Forhidrol administration increased beneficial effect on the lipoprotein profile in vivo}

Since rabbit is a species with natural high levels of CETP, in vivo study was conducted in male New Zealand rabbits to assure the effect of CETP inhibition by Forhidrol on HDL, LDL and triglycerides levels. The treated rabbits were fed a normal diet and supplemented with $37.5 \mathrm{mg}$ Forhidrol $/ 1.5 \mathrm{~kg}$ body weight/day, while non-treated rabbits were fed a normal diet without Forhidrol. However, we found that the variation of HDL, LDL, triglycerides and CETP values between individuals in each group were high, which consequently increased the deviation values.

The correlation of HDL, LDL, triglycerides and plasma CETP activity changes after 30 days between control and treatment groups are presented in Table 2. The changes were calculated based on the ratio to each baseline. After 4 weeks of treatment, HDL levels was reduced by $9.46 \pm 7.40 \%$ in placebo group and elevated by $19.59 \pm 33.51 \%$ in the treatment groups. Conversely, LDL and
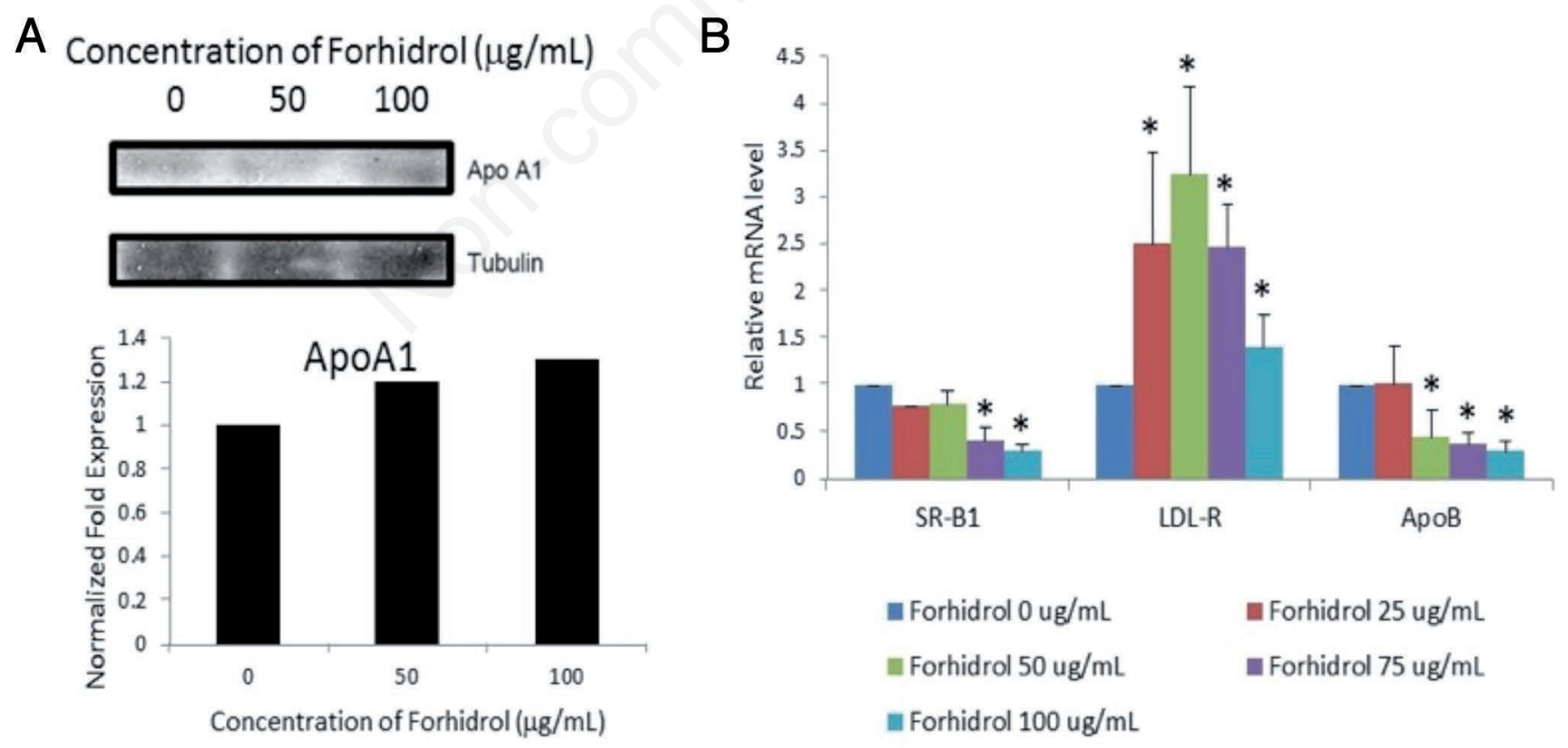

Figure 3. Forhidrol slightly increases ApoA-I protein level (A). Forhidrol down-regulates scavenger receptor class B type 1 (SR-B1) and apolipoprotein B (ApoB) genes expressions and up-regulates low-density lipoprotein receptor (LDL-R) gene expression at mRNA level (B). Hepatocellular carcinoma cells were incubated with Forhidrol $(75 \mu \mathrm{g} / \mathrm{mL})$ for $24 \mathrm{~h}$ and total RNA was extracted. Protein level was analyzed by western blot. The mRNA levels of SR-B1, LDL-R and ApoB genes were analyzed by real-time polymerase chain reaction and normalized to $\beta$-actin. Results are expressed as mean $\pm S D$ of two independent experiments. ${ }^{*} \mathrm{P}<0.05$ indicates a significant difference compared to control. 
triglyceride levels were reduced after 4 weeks of Forhidrol treatment. The increase of LDL, triglyceride levels and CETP activity in the control group were $3.89 \pm 20.2 \%, 23.48 \pm 32.53 \%$ and $1.73 \pm 4.1 \%$, respectively, while those levels were reduced in the treatment groups by $0.94 \pm 46.01 \%, 0.34 \pm 10.94 \%$ and $1.23 \pm 1.09 \%$, respectively (Table 2). In Forhidrol treatment group, the change in HDL levels was negatively correlated to the change in CETP activity, while the change in LDL levels was positively correlated to the change in CETP activity. It is well established that elevated triglyceride and LDL levels are the major risk factors for CVD.

\section{Effect of Forhidrol on blood pressure level}

CYP11B1 and CYP11B2 have been reported to be correlated with blood pressure in human and animal models. In this study, we also investigated the effect of Forhidrol on those genes. Forhidrol was shown to down-regulate the expression of CYP11B1 and CYP11B2 by $80-90 \%$ and $40-50 \%$, respectively (Figure 7 ). Although there was a higher level of CYP11B1 expression observed at $100 \mu \mathrm{g} / \mathrm{mL}$ of Forhidrol, the expression of this gene was still significantly lower compared to control. Therefore, it appeared that Forhidrol may not elevate blood pressure.

\section{Discussion}

Decreased HDL level has been well-known as one of the major risk factors of coronary heart disease. However, there are no

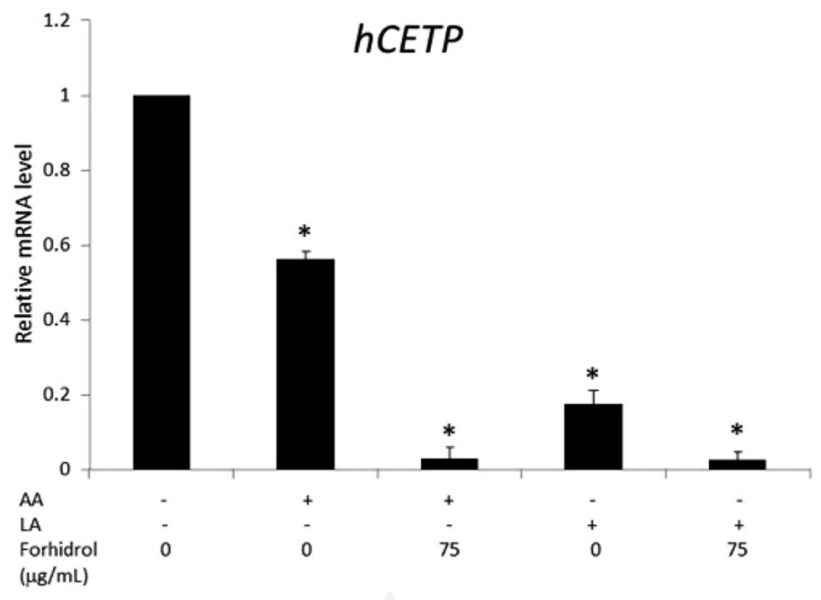

Figure 4. Forhidrol and Polyunsaturated fatty acids synergistically reduce cholesteryl ester transfer protein (CETP) at transcriptional levels. Hepatocellular carcinoma cells were treated with Forhidrol $(75 \mathrm{ug} / \mathrm{mL})$ and/or arachidonic acid (AA) or linoleic acid (LA) $(30 \mu \mathrm{M})$ and total RNA was extracted after $24 \mathrm{~h}$ of incubation. The expression of CETP mRNA was analyzed by real-time polymerase chain reaction and normalized to $\beta$-actin. Results are expressed as mean \pm SD of two independent experiments. ${ }^{*} \mathbf{P}<\mathbf{0 . 0 5}$ indicates a significant difference compared to control.
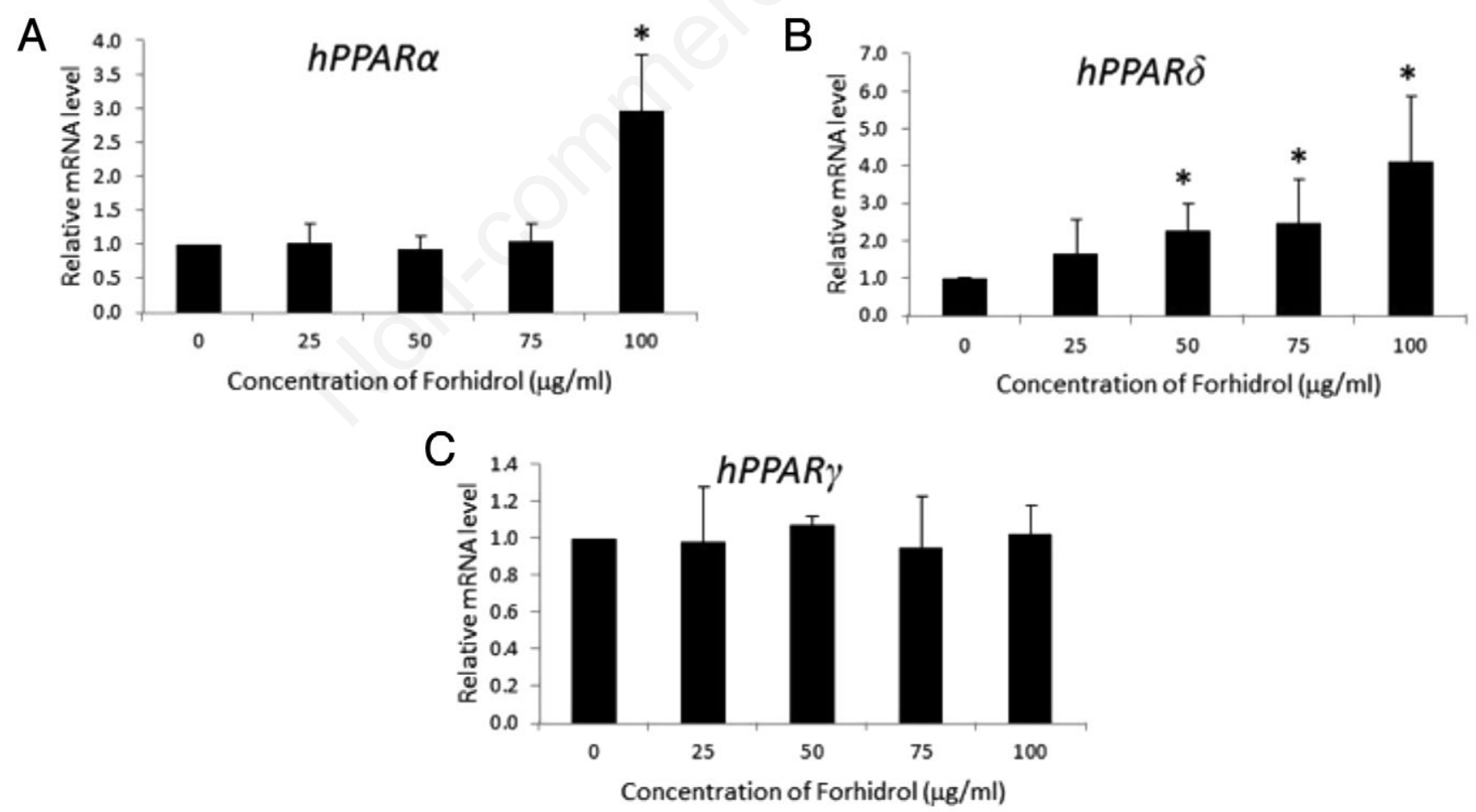

Figure 5. Forhidrol significantly increases the expression of peroxisome proliferator-activated receptor $\alpha($ PPAR $\alpha)$ at a concentration of $100 \mathrm{mg} / \mathrm{mL}$ (A) and peroxisome proliferator-activated receptor $\delta$ (PPAR $\delta$ ) in a dose-dependent manner (B). Forhidrol did not affect peroxisome proliferator-activated receptor $\gamma(\operatorname{PPAR} \gamma)$ expression (C). Hepatocellular carcinoma cells were treated with Forhidrol $(0$ $100 \mu \mathrm{g} / \mathrm{mL}$ ) for $24 \mathrm{~h}$. Total RNA was isolated and mRNA levels of PPAR $\alpha$, PPAR $\delta$ and PPAR $\gamma$ were analyzed by real-time polymerase chain reaction. Glyceraldehyde 3-phosphate dehydrogenase was used as the internal loading control. Results are expressed as mean \pm SD of three independent experiments. ${ }^{*} \mathbf{P}<0.05$ indicates a significant difference compared to the control. 
therapies that substantially raise HDL levels. Recently, inhibition of CETP has been proposed as a promising strategy to raise HDL levels. ${ }^{3,4}$ CETP is a major determinant of plasma levels of HDL in humans by mediating the exchange of cholesteryl esters in HDL particles for triglycerides in LDL and VLDL particles through RCT, a pathway by which peripheral cell cholesterol can be returned to the liver for further catabolism. ${ }^{12,13}$

Since the expression and activity of CETP is one of the determinants of plasma HDL levels in human, in the present study we focused on investigating the potential activity of Forhidrol on affecting CETP. Forhidrol reduced CETP mRNA level in dose- and time-dependent manners. The same trend was also found at the protein level, however, Forhidrol activity on reducing CETP mRNA level was much higher than that in the protein level. These data suggested that Forhidrol is more likely to affect CETP at its transcriptional level, which is in line with other reports that found mRNA level as the major determinant of secreted CETP protein. ${ }^{30-}$ 32 Moreover, Forhidrol also dose-dependently reduced CETP activity in mediating lipid transfer.

Some regulatory elements were known to control CETP transcription by modulating its promoter, which include LXR, 5,33,34 SREBP, ${ }^{6}$ LRH-1, ${ }^{5}$ ARP-1, CCAAT/enhancer-binding protein $(\mathrm{C} / \mathrm{EBP}),{ }^{35}$ trans retinoic acid, ${ }^{36}$ and $\mathrm{Sp} 1$ and $\mathrm{Sp} 3$ transcription factors. ${ }^{37,38}$ However, experiment on the specific regulatory pathways that directly affect CETP transcription is still limited. ${ }^{2}$ In this study, we investigated several regulatory elements of CETP at mRNA level. We found alterations in SREBP-1 and LXR at mRNA level isolated from Forhidrol-treated HepG2 cells, but not in LRH1 and ARP-1 at mRNA level. LXRs are nuclear receptors that form heterodimers with RXRs. ${ }^{32}$ It is highly expressed in the liver and plays a central role in maintaining cholesterol homeostasis in the liver. ${ }^{34}$ We found that the transcription level of LXR $\alpha$ was declined after Forhidrol administration. Reduced expression of this gene may subsequently affect the transcription of SREBP-1 since LXR/RXR complex was identified as the activator of SREBP-1 promoter. . $^{5,32}$ With regards to the previous study, we found a similar circumstance where SREBP-1 expression at mRNA level was seen to be declined due to Forhidrol administration, confirming the correlation of LXR and SREBP-1 genes.

SREBPs are synthesized in endoplasmic-reticulum membrane, proteolytically cleaved to the active form and released to the nucleus to activate the transcription of some related genes, including CETP. Chouinard et al. ${ }^{6}$ found that SREBP-1 contributes to CETP expression in liver and adipose tissue. LXRs bind to a site of CETP promoter and activate the transcription process. ${ }^{5,39}$ Honzumi et al. ${ }^{39}$ reported that LXR agonist enhanced plasma CETP activity and resulted in decreased HDL in vitro and in vivo. Therefore, the mechanism of CETP transcription is complex and requires interaction between LXR and SREBP transcription factors. ${ }^{40,41}$ Our findings indicated that down-regulation of LXR and SREBP by Forhidrol subsequently reduced CETP mRNA level.

Forhidrol was further found to influence lipoprotein receptors and apolipoprotein expressions. Previous studies have shown the association between CETP deficiency or mutation with changes in lipoprotein receptors or apolipoprotein expressions. ${ }^{39,42}$

ApoA-I presents in majority of HDL particles by constituting approximately $70 \%$ of apolipoprotein content in HDL protein. ${ }^{43,44}$ Immunoblotting study revealed that Forhidrol up-regulated ApoAI protein in HepG2-treated cells. ApoA-I mediates cholesterol removal in RCT pathway where cholesteryl esters (CEs) bind to the apolipoproteins. Through several steps which were catalyzed by several related enzymes, ApoA-I particles are converted to HDL particles, while carrying cholesteryl esters. ${ }^{45}$ As a consequence,

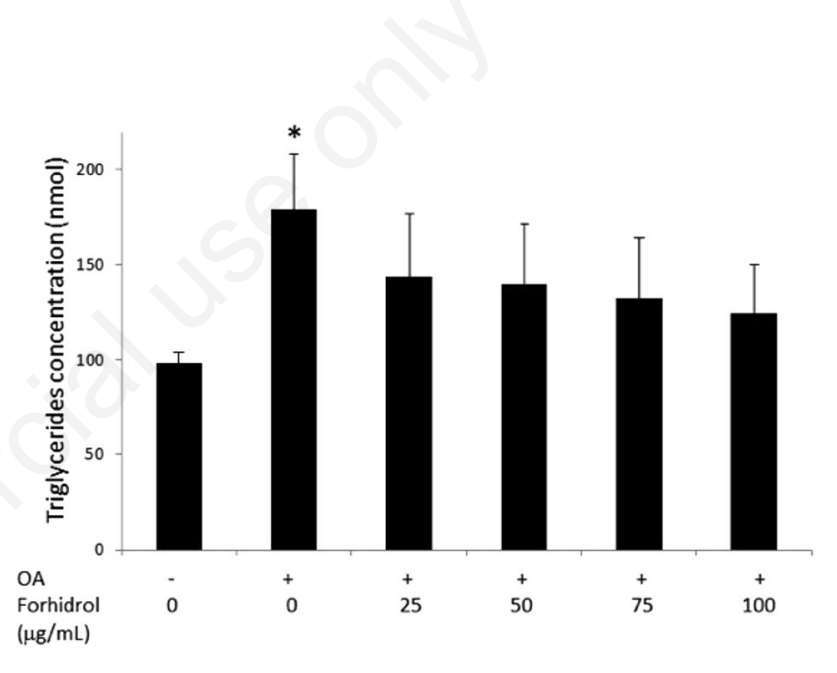

Figure 6. Forhidrol slightly decreases triglyceride synthesis in hepatocellular carcinoma (HepG2) cells. HepG2 cells were incubated with Forhidrol $(0-100 \mu \mathrm{g} / \mathrm{mL})$ for $24 \mathrm{~h}$ and triglycerides were extracted. Cells were pre-treated with $0.5 \mathrm{mM}$ oleic acid to induce triglyceride synthesis and used as negative control. Human triglycerides abbexa enzyme-linked immunosorbent assay kit was used to analyze triglyceride level in vitro. Results are expressed as mean $\pm S D$ of three independent experiments. ${ }^{*} \mathbf{P}<0.05$ indicates a significant difference compared to the control.

Table 2. Comparison of cholesteryl ester transfer protein (CETP)-lowering effect on plasma lipoprotein levels at baseline (0 day) and after 30 days of treatment with Forhidrol in New Zealand white rabbits. Animals in control group fed a normal diet, while those in treated groups fed the same diet supplemented with Forhidrol at a dose of $37.5 \mathrm{mg} / 1.5 \mathrm{~kg}$ of body weight/day. The amount of plasma lipids and CETP activity were measured using blood samples of 12-h fasted rabbits which were withdrawn from ear veins. Values are expressed as $\mu \mathrm{g} / 100 \mu \mathrm{L}$ for high-density lipoprotein (HDL) and low-density lipoprotein (LDL)-cholesterol, nmol/100 $\mu \mathrm{L}$ for triglycerides (TG), and $\mathrm{pmol} / \mu \mathrm{L} / \mathrm{h}$ for CETP activity.

\begin{tabular}{lccccc} 
Group & Tlime & HDL-C & LDL-C & TG & CETP activity \\
Control & Baseline (Day 0) & $0.83 \pm 0.69$ & $1.52 \pm 0.36$ & $23.28 \pm 16.65$ & $138.13 \pm 12.38$ \\
& Day 30 & $0.81 \pm 0.64$ & $1.58 \pm 0.50$ & $29.57 \pm 24.34$ & $140.23 \pm 9.30$ \\
Forhidrol treatment & B change & $\downarrow 9.46 \pm 7.49$ & $\uparrow 3.89 \pm 20.2$ & $\uparrow 23.48 \pm 32.53$ & $1.73 \pm 4.11$ \\
& Baseline (Day 0) & $1.26 \pm 0.24$ & $2.04 \pm 0.87$ & $48.06 \pm 10.09$ & $144.43 \pm 4.04$ \\
& Day-30 & $1.54 \pm 0.63$ & $1.75 \pm 0.42$ & $48.08 \pm 11.93$ & $142.65 \pm 4.80$ \\
& \% change & $19.59 \pm 33.51$ & $0.94 \pm 46.01$ & $0.34 \pm 10.94$ & $1.23 \pm 1.09$ \\
\hline
\end{tabular}

The mean of individual percent $(\%)$ changes $( \pm \mathrm{SD})$ relative to baseline. Results are expressed as mean values \pm SD of five subjects in each group. 
ApoA-I concentration correlates positively to HDL level. ${ }^{43,45} \mathrm{HDL}$ has been proven to possess protective properties against atherosclerosis by delivering CEs to the liver for disposal as bile acids. ${ }^{3,45}$ In addition, study in transgenic mice showed that ApoA-I overexpression was able to elevate HDL level and protect against atherosclerosis. ${ }^{46}$ This reveals other property of Forhidrol in controlling cholesterol level in the body and, therefore, reducing the occurrence of atherosclerosis.

Effect of Forhidrol on SR-B1, a cell surface glycoprotein that acts as HDL receptor and mediates selective uptake of HDL-CE, were also investigated. Expression of SR-B1 gene isolated from HepG2 cells was down-regulated by Forhidrol administration. Transcriptional regulation of SR-B1 appears to be due to SR-B1 promoter binding sites for a number of transcription factors, including C/EBP, SF-1 and SREBP. ${ }^{47}$ Since SREBP is a sterol transcription factor that induces SR-BI gene expression, ${ }^{48}$ the reduced expressions of SR-B1 showed in this study may also be associated with the down-regulation of SREBP-1 during CETP inhibition by Forhidrol. The reduction of SR-B1 was also reported in Fibrates, a normolipid drug class used in atherogenic dyslipidemia that raise HDL and decrease triglyceride levels. ${ }^{49}$ In their study, Mardones et al. ${ }^{49}$ described a novel effect of Fibrates as an alternative mechanism in modulating HDL metabolism through the suppression of SR-B1 expression. In vivo study in rats indicated that SR-B1 expression is modulated by feedback mechanism in response to changes in cellular cholesterol stores. ${ }^{50}$ Huang et al. ${ }^{45}$ also reported that although acute suppression of CETP expression lead to an elevation in cellular cholesterol stores, the return of HDLCE to hepatocytes via SR-BI pathway was inhibited, which further manifested the dual effects of CETP inhibition in HDL metabolism and further increase the formation of HDL and suppression HDLCE catabolism via SR-B1 pathway. ${ }^{45,51}$ Furthermore, decreased SR-B1 by Forhidrol might be a beneficial mechanism to suppress HDL catabolism. In another hand, SR-B1 is required to uptake cholesterol of HDL-CE to the liver. ${ }^{51}$ Collet et al. stated that HDL$\mathrm{CE}$ from plasma to the liver can be transported by either indirect pathway (by transferring to other lipoproteins followed by hepatic receptor-mediated endocytosis) or direct pathway (via SR-B1 and selective uptake). ${ }^{51}$ It seemed that Forhidrol transported HDL-CE to the liver via the indirect pathway.

Other important changes were also observed in LDL-R and

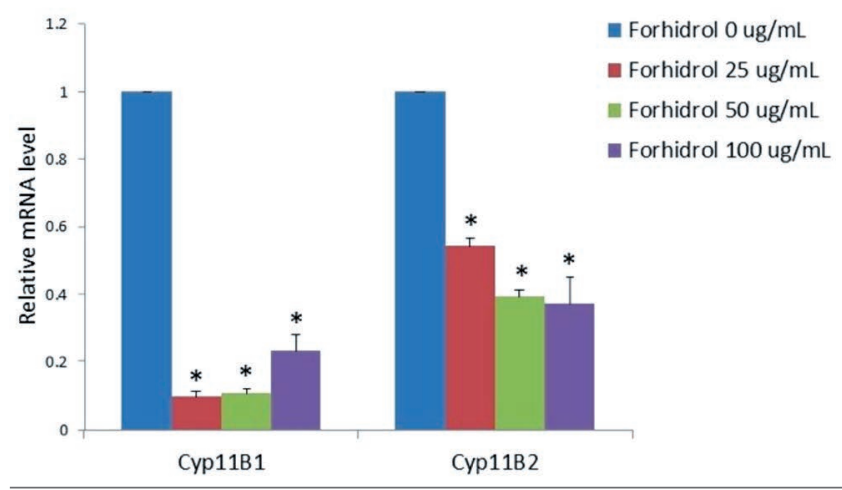

Figure 7. Forhidrol possibly does not increase blood pressure. Hepatocellular carcinoma cells were treated with Forhidrol (0$100 \mu \mathrm{g} / \mathrm{mL}$ ) for $24 \mathrm{~h}$. Total RNA was isolated and mRNA levels of CYP11B1 and CYP11B2 were analyzed by real-time polymerase chain reaction. $\beta$-actin was used as the internal loading control. apolipoprotein B (ApoB), in which their expressions were upregulated and down-regulated, respectively, after treatment with Forhidrol in HepG2 cells (Figure 3B). Deficiency of CETP and SREBP-1 may result in qualitative changes of ApoB, which is the major component of LDL particles, as well as LDL-R. ${ }^{52}$ Evidence showed that SREBP-1 was independently identified as a transcription factor that activate LDL-R gene expression under sterol depletion condition in cell culture. ${ }^{6}$ Furthermore, metabolic turnover of LDL and ApoB may be substantially increased due to up-regulation of LDL-R pathway. Based on these findings, where Forhidrol up-regulated LDL-R and down-regulated ApoB genes, a more comprehensive atheroprotective mechanism of Forhidrol was further revealed.

Prior studies reported that CETP was affected by various fatty acids. ${ }^{30}$ Here, we also investigated the effects of two PUFAs, e.g. AA and LA, on CETP mRNA level. The results exhibited that CETP expression in PUFA-treated HepG2 cells declined drastically (Figure 4). Surprisingly, when PUFAs treatment was combined with Forhidrol, CETP inhibition was higher than PUFA treatment alone. PUFA has been reported to override pro-lipogenic effects through the modulation of pro-lipogenic genes, such as PPARs, SREBP and LXR. ${ }^{53}$ As Forhidrol also modulated the same pro-lipogenic genes, it might be indicated that Forhidrol and PUFAs acted synergistically to reduce CETP at transcriptional level.

PPARs are transcription factors that play crucial roles in lipid and lipoprotein metabolism, which consists of three proteins including alpha, beta/delta and gamma. ${ }^{54}$ Considerable evidences indicated that stimulation of PPARs in atherosclerosis condition has been reported to: i) inhibit hepatic triglyceride production; ii) increase lipoprotein lipase-mediated triglyceride lipolysis; iii) provide a higher affinity of remnants for the LDL-R; iv) enhance human ApoA-I and ApoA-II synthesis; ${ }^{55}$ and v) reduce CETP expression. ${ }^{56,57}$ Several studies reported that PPARs agonism is beneficial due to their effect on improving different profiles of atherosclerosis. A dual PPAR $\alpha \gamma$ agonist blocks the progression of pre-existing atherosclerosis by reducing triglyceride and LDL levels as well as increasing HDL level in transgenic mice. ${ }^{58}$ Another study reported that PPAR $\gamma$ suppressed CYP11B2 expression in vitro. ${ }^{59}$ PPAR $\delta$ agonist serves as atheroprotective agent by decreasing monocyte chemoattractant protein 1 (MCP-1) and intracellular adhesion molecule 1 (ICAM-1) in LDL-R (-/-) mice. ${ }^{60}$ Thus, regulations of these proteins remain an attractive therapeutic target for drug development in the treatment of chronic inflammatory diseases such as atheroschlerosis. ${ }^{54}$ Our findings revealed that Forhidrol treatment increased PPARs gene expressions in HepG2 cells, especially PPAR $\delta$ and PPAR $\alpha$, which may be associated to the changes of LDL-R expression and LDL level, respectively. Although we did not evaluate the effect of Forhidrol on PPARs activities, there might be a direct correlation between PPARs expression and lipid metabolism, as higher PPARs expression may contribute to higher activation of PPARs. This statement was also supported by the activity of Forhidrol in the reduction of triglycerides levels. Triglycerides are reported as a substance that is not directly atherogenic, however, since they are also the component of LDL molecules which exert negative effect in atheroschlerosis, high level of triglycerides represents an important biomarker of cardiovascular disease. ${ }^{61}$ The reduction of PPARs expression and triglycerides level by Forhidrol may support its beneficial effects in reducing LDL-CE.

In vivo study in New Zealand rabbits was also conducted to affirm the effects of Forhidrol in plasma lipid profiles and CETP activity. Inclusion of Forhidrol in the diet resulted in a decreased CETP activity which subsequently led to an elevation of HDL level 
compared to the control group. CETP deficiency in the treated animal models exhibited a reduced exchange of CE from HDL particles to triglycerides in LDL particles. This condition was observed in our study wherein LDL and triglyceride levels were reduced in the treatment group. The present study confirmed that inclusion of Forhidrol in the diet resulted in an elevation of plasma HDL level by specific inhibition of plasma CETP activity in the experimental rabbits. Although low significance alterations were found in the Forhidrol-treated rabbits compared to the control groups, the data showed clear trends that Forhidrol treatment improved atherosclerosis condition by increasing HDL level and reducing LDL, triglycerides and CETP level.

In addition to the pharmacodynamic data, we also investigated the effect of Forhidrol as CETP inhibitor on other factors. One of CETP inhibitor that has been clinically tested is torcetrapib.

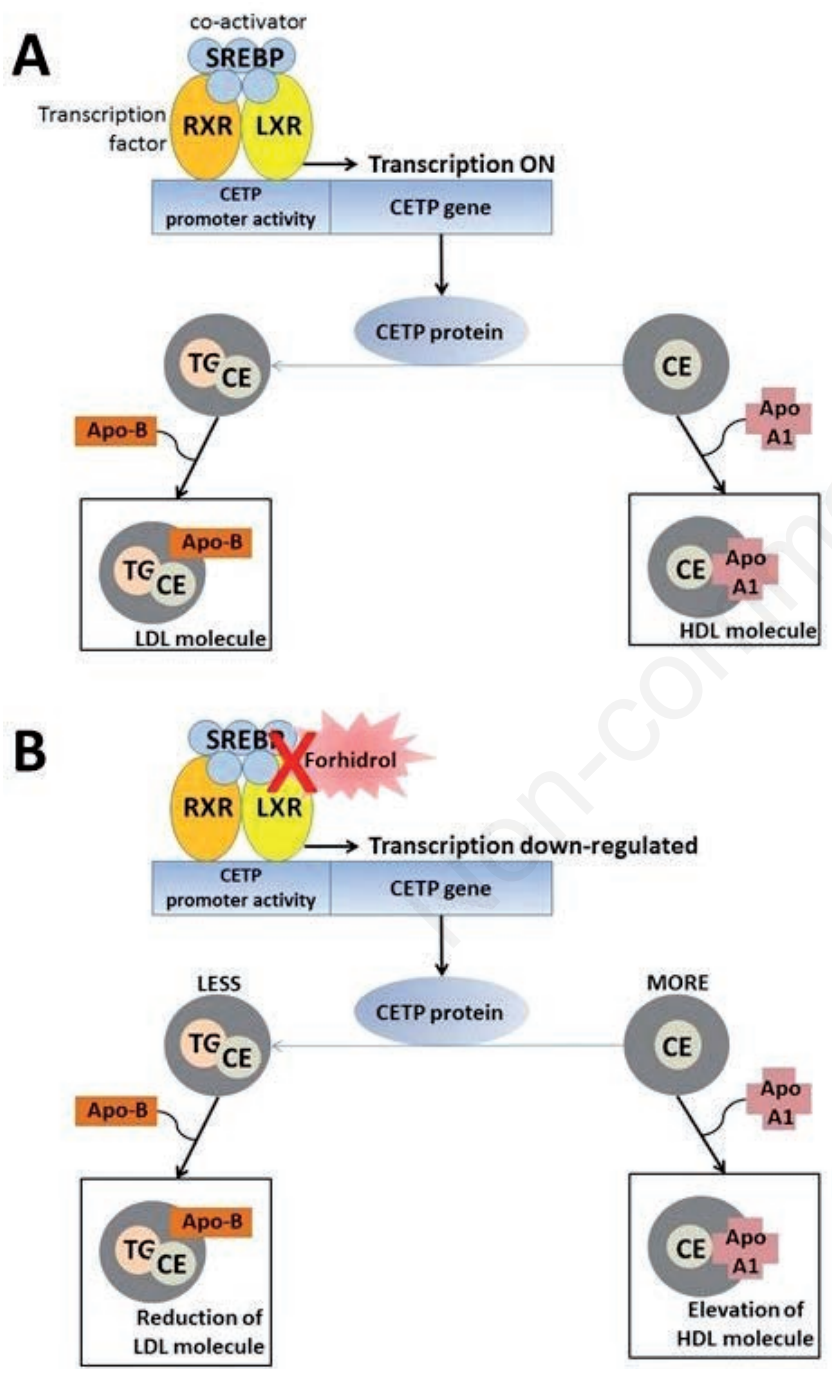

Figure 8. Forhidrol inhibits cholesteryl ester transfer protein (CETP) expression via down-regulation of liver $X$ receptor (LXR) and sterol regulatory element-binding protein 1 (SREBP-1) and subsequently results in a higher level of HDL. (A) The normal transcription and role of CETP; (B) The Action of Forhidrol on CETP inhibition which results in the elevation of high-density lipoprotein (HDL) level.
Brousseau et al. ${ }^{62}$ found that torcetrapib markedly increased HDL level and also decreased LDL level in patients with low HDL level. During the study, it was found that inhibition activity of torcetrapib was associated with an increase in blood pressure due to the stimulation of aldosterone and cortisol secretion through certain molecule-specific effects that are unrelated to CETP inhibition, which further led to a high mortality rate in torcetrapib-treated patients. ${ }^{63} \mathrm{~A}$ study at mRNA level revealed that torcetrapib increased the expression of CYP11B1 and CYP11B2 which are the key enzymes in the last step of cortisol and aldosterone biosynthesis pathway, respectively. ${ }^{64}$ Increased production and secretion of aldosterone and cortisol were found to further lead to blood pressure elevation. ${ }^{65}$ Unlike torcetrapib, Forhidrol reduced CYP11B1 and CYP11B2 transcription (Figure 7) which suggested that Forhidrol did not result in the elevation of blood pressure. Based on the present result, Forhidrol may act as a safe preference of CETP inhibitor which does not affect the blood pressure.

\section{Conclusions}

In conclusion, our present study indicated that Forhidrol, a bioactive fraction derived from P. macrocarpa (Scheff.) Boerl., possesses several properties which increases RCT pathway by decreasing CETP expression and inhibiting its activity, as described in Figure 8. This bioactive fraction caused down-regulation of CETP transcriptional regulatory genes, including SREBP-1 and LXR $\alpha$ which resulted in an inhibition of CETP at mRNA and protein levels. Forhidrol also affected other important features of atherosclerosis such as increased PPARs and repressed triglyceride level, which further linked to the changes of atherosclerosis profiles such as the balance of LDL-HDL particles. Preliminary in vivo study in rabbit showed that Forhidrol administration has a beneficial effect on lipoprotein profile, which includes a decreased LDL level and an increased HDL level. These beneficial effects may be partially mediated via down-regulation of CETP. Additionally, our findings may be useful in the contribution of potential and safe therapy for atherosclerosis.

\section{References}

1. Barter P. The role of HDL-cholesterol in preventing atherosclerotic disease. Eur Heart J 2005;7:F4-8.

2. Gaudet F, Ginsburg GS. Transcriptional regulation of the cholesteryl ester transfer protein gene by the orphan nuclear hormone receptor apolipoprotein AI regulatory protein-1. J Biol Chem 1995;270:29916-22.

3. Shah PK. Inhibition of CETP as a novel therapeutic strategy for reducing the risk of atherosclerotic disease. Eur Heart J 2007;28:5-12.

4. Zhou H, Li Z, Silver DL, Jiang XC. Cholesteryl ester transfer protein (CETP) expression enhances HDL cholesteryl ester liver delivery, which is independent of scavenger receptor BI, LDL receptor related protein and possibly LDL receptor. Biochim Biophys Acta 2006;1761:1482-8.

5. Luo Y, Liang CP, Tall AR. The orphan nuclear receptor LRH-1 potentiates the sterol-mediated induction of the human CETP gene by liver X receptor. J Biol Chem 2001;276:24767-73.

6. Chouinard RA, Luo Y, Osbornes TF, et al. Sterol regulatory element binding protein-1 activates the cholesteryl ester transfer 
protein gene in vivo but is not required for sterol up-regulation of gene expression. J Biol Chem 1998;273:22409-14.

7. Yamashita S, Hirano K, Sakai N, Matsuzawa Y. Molecular biology and pathophysiological aspects of plasma cholesteryl ester transfer protein. Biochim Biophys Acta 2000;1529:257-75.

8. Sandhofer A, Kaser S, Ritsch A, et al. Cholesteryl ester transfer protein in metabolic syndrome. Obesity 2006;14:812-8.

9. Inazu A, Brown ML, Hesler CB, et al. Increased high-density lipoprotein levels caused by a common cholesteryl ester transfer protein gene mutation. N Engl J Med 1990;323:1234-8.

10. Assmann G, Gotto AM. HDL cholesterol and protective factors in atherosclerosis. Circulation 2004;109:III-8-14.

11. Barter PJ, Brewer HB, Chapman MJ, et al. Cholesteryl ester transfer protein: a novel target for raising HDL and inhibiting atherosclerosis. Arterioscler Thromb Vasc Biol 2003;23:160-7.

12. de Grooth GJ, Klerkz AHEM, Stroes ESG, et al. A review of CETP and its relation to atherosclerosis. J Lipid Res 2004;45:1967-74.

13. Ohashi R, Mu H, Wang X, et al. Reverse cholesterol transport and cholesterol efflux in atherosclerosis. Int J Med 1998;98:84556.

14. Brewer B. Increasing HDL cholesterol levels. N Engl J Med 2004;350:1491-4.

15. Conca P, Franceschini G. Synthetic HDL as a new treatment for atherosclerosis regression: has the time come. Nutr Metab Cardiovasc Dis 2008; 18:329-35.

16. Clark WR, Sutfin TA, Ruggeri RB. Raising high-density lipoprotein in humans through inhibition of cholesteryl ester transfer protein: an initial multidose study of torcetrapib. Arterioscler Thromb Vasc Biol 2004;24:490-7.

17. Wirawan IGPI. Phaleria macrocarpa as antihypertension. J Majority 2015;4:24-8.

18. Sudewa IWB, Ismanto AY, Rompas S. Effect of Mahkota Dewa (Phaleria macrocarpa) Fruit on Blood Pressure Reduction in Subjects with Hypertension in Werdhi Agung, Dumoga Tengah, Bolaang Mongondow District. J Keperawatan 2014;2.

19. Muhtadi A, Hendriani R, Mustarichie R. Pharmacological screening of various Indonesian herbals potentially used as antidiabetic. Int Res J Pharmaceut Appl Sci 2013;3:90-5.

20. Ali RB, Atangwho IJ, Kuar N, et al. Hypoglycemic and antihyperglycemic study of Phaleria macrocarpa fruits pericarp. J Med Plant Res 2012;6:1982-90.

21. Andriani Y, Tengku-Muhammad TS, Mohamad H, et al. Phaleria macrocarpa Boerl. (Thymelaeaceae) leaves increase SR-BI expression and reduce cholesterol levels in rats fed a high cholesterol diet. Molecules 2015;20:4410-29.

22. Chong SC, Dollah MA, Chong PP, Maha A. Phaleria macrocarpa (Scheff.) Boerl fruit aqueous extract enhances LDL receptor and PCSK9 expression in vivo and in vitro. J Ethnopharmacol 2011;137:817-27.

23. Sulistyoningrum E, Setiawati. Phaleria macrocarpa reduces glomerular growth factor expression in alloxan-induced diabetic rats. Universa Medicina 2013;32:71-9.

24. Tandrasasmita OM, Lee JS, Baek SH, Tjandrawinata RR. Induction of cellular apoptosis in human breast cancer by DLBS1425, a Phaleria macrocarpa compound extract, via down-regulation of P13-kinase/AKT pathway. Cancer Biol Ther 2010;10:1-11.

25. Tjandrawinata RR, Arifin PF, Tandrasasmita OM, et al. DLBS1425, a Phaleria macrocarpa (Scheff.) Boerl. extract confers anti proliferative and proapoptosis effects via eicosanoid pathway. J Exp Ther Oncol 2010;8:187-201.

26. Faried A, Kurnia D, Faried LS, et al. Anticancer effects of gallic acid isolated from Indonesian herbal medicine, Phaleria macrocarpa (Scheff.) Boerl. on human cancer cell lines. Int J Oncol 2006;30:605-13.

27. Triastuti A, Choi JW. Protective effects of ethyl acetate fraction of Phaleria macrocarpa (Scheff.) Boerl. on oxidative stress associated with alloxan-induced diabetic rats. J Ilmiah Farmasi 2008;5:9-17.

28. Sugiwati S, Kardono LBS, Bintang M. $\alpha$-glucosidase inhibitory activity and hypoglycemic effect of Phaleria macrocarpa fruit pericarp extracts by oral administration to rats. J Appl Sci 2006;6:2312-6.

29. Armenia EF, Widya RM, Rusdi DJ, Netty M. Antiatherosclerotic effect and liver toxicity of ethanolic extract of Phaleria macrocarpa (Scheff. Boerl) fruit on Japanese Quail. Asian Symposium on Medicinal Plants, Spices and other natural product XII (ASOMP), Padang, Indonesia; 2006.

30. Hirano R, Igarashi O, Kondo K, et al. Regulation by long-chain fatty acids of the expression of cholesteryl ester transfer protein HepG2 cells. Lipids 2001;36:401-6.

31. Oram JF, Lawn RM, Garvin MR, Wade DP. ABCA1 is the cAMPinducible apolipoprotein receptor that mediates cholesterol secretion from macrophages. J Biol Chem 2000;275:34508-11.

32. Yoshikawa T, Shimano H, Yahagi N, et al. Polyunsaturated fatty acids suppress sterol regulatory element-binding protein $1 \mathrm{c}$ promoter activity by inhibition of liver X receptor (LXR) binding to LXR response elements. J Biol Chem 2002;277:705-17.

33. Naik SU, Wang X, da Silva JS, et al. Pharmacological activation of liver X receptors promotes reverse cholesterol transport in vivo. Circulation 2006;113:90-7.

34. Hu YW, Zheng L, Wang Q. Regulation of cholesterol homeostatis by liver X receptor. Clin Chim Acta 2010;411:617-25.

35. Agellon LB, Zhang P, Jiang XC, et al. The CCAAT/enhancerbinding protein trans-activates the human cholesteryl ester transfer protein gene promoter. J Biol Chem 1992;267:22336-9.

36. Jeoung NH, Jang WG, Nam JI, et al. Identification of retinoic acid receptor element in human cholesteryl ester transfer protein gene. Biochem Biophys Res Commun 1999;258:411-5.

37. Dachet C, Poirier O, Cambien F, et al. New functional promoter polymorphism, CETP -629, in cholesteryl ester transfer protein (CETP) gene related to CETP mass and high density lipoprotein cholesterol levels. Arterioscler Thromb Vasc Biol 1999;20:507-15.

38. Goff WL, Guerin M, Petit L, et al. Regulation of human CETP gene expression: role of SP1 and SP3 transcription factors at promoter sites -690, -629, and -37. J Lipid Res 2003;44:1322-31.

39. Honzumi S, Shima A, Hiroshima A, et al. LXR $\alpha$ regulates human CETP expression in vitro and in transgenic mice. Atherosclerosis 2010;212:139-45.

40. Gauthier B, Robb M, Gauder F, Ginsburg GS, McPherson R. Characterization of a cholesterol response elemen (CRE) in the promoter of the cholesteryl ester transfer protein gene: functional role of the transcription factor SREBP-1a, -2, and YY1. J Lipid Res 1999;40:1284-93.

41. Luo Y, Tall AR. Sterol upregulation of human CETP expression in vitro and in transgenic mice by LXR element. J Clin Invest 2000;105:513-20.

42. Miller M, Rhyne J, Hamlette S, et al. Genetics of HDL regulation in humans. Curr Opin Lipidol 2003;14:273-9.

43. Lewis GF, Rader DJ. New insights into the regulation of HDL metabolism and reverse cholesterol transport. Circ Res 2005;96:1221-32.

44. Superko HR. Advanced lipoprotein testing and subfractionation are clinically useful. Circulation 2009;119:2383-95. 
45. Huang Z, Inazu A, Kawashiri M, et al. Dual effects on HDL metabolism by cholesteryl ester transfer protein inhibition on HepG2 cells. Am J Physiol Endrocrinol Metab 2003;284:1210-9.

46. Rubin EM, Krauss RM, Spangler EA, et al. Inhibition of early atherogenesis in transgenic mice by human apolipoprotein AI. Nature 1991;353:265-7.

47. Krieger M. Scavenger receptor class B type I is a multiligand HDL receptor that influences diverse physiologic systems. J Clin Invest 2001;108:793-7.

48. Lopez D, McLean MP. Sterol regulatory element-binding protein-1a binds to cis element in the promoter of the rat high density lipoprotein receptor SR-BI gene. Endrocrinol 1999;140: 5669-81.

49. Mardones P, Pilon A, Bouly M, et al. Fibrates down-regulate hepatic scavenger receptor class B type 1 protein expression in mice. Am Soc Biochem Mol Biol 2003;278:7884-90.

50. Fluiter K, van der Westhuijzen DR, van Berkel TJ. In vivo regulation of scavenger receptor $\mathrm{BI}$ and the selective uptake of high density lipoprotein cholesteryl esters in rat liver parenchymal and kupffer cells. J Biol Chem 1998;273:8434-8.

51. Collet X, Tall AR, Serajuddin H, et al. Remodeling of HDL by CETP in vivo and by CETP and hepatic lipase in vitro results in enhanced uptake of HDL CE by cells expressing scavenger receptor B-I. J Lipid Res 1999;40:1185-93.

52. Imes CC, Austin MA. Low-density lipoprotein cholesterol, apolipoprotein $\mathrm{B}$, and risk of coronary heart disease: from familial hyperlipidemia to genomics. Biol Res Nurs 2013;15:292-308.

53. Sampath H, Ntambi JM. Polyunsaturated fatty acid regulation of genes of lipid metabolism. Ann Rev Nutr 2005;25:317-40.
54. Duval C, Chinetti G, Trottein F, et al. The role of PPARs in atheroschlerosis. Trends Mol Med 2002;8:422-30.

55. Staels B, Dallongeville J, Auwerx J, et al. Mechanism of action of fibrates on lipid and lipoprotein metabolism. Circulation 1998;98:2088-93.

56. Beyer TP, Chen Y, Porter RK, et al. Peroxisome proliferatoractivated receptor- $\alpha$ agonists regulate cholesterol ester transfer protein. Lipids 2008;43:611-8.

57. van der Hoogt CC, de Haan W, Westerterp M, et al. Fenofibrate increases HDL-cholesterol by reducing cholesteryl ester transfer protein expression. J Lipid Res 2007;48:1761-3.

58. van der Hoorn JWA, Jukema JW, Havekes LM, et al. The dual PPAR $\alpha / \gamma$ agonist tesaglitazar blocks progression of pre-existing atherosclerosis in APOE*3Leiden.CETP transgenic mice. Br J Pharmacol 2009;156:1067-75.

59. Uruno A, Matsuda K, Noguchi N, et al. Peroxisome proliferatoractivated receptor $\gamma$ suppresses CYP11B2 expression and aldosterone production. J Mol Endocrinol 2011;46:37-49.

60. Graham TL, Mookherjee C, Suckling KE, et al. The PPAR $\delta$ agonist GW0742X reduces atherosclerosis in $\mathrm{LDLR}^{-/}$mice. Atherosclerosis 2005;181:29-37.

61. Talayero BG, Sacks FM. The role of triglycerides in atherosclerosis. Curr Cardiol Rep 2011;13:544-52.

62. Brousseau ME, Schaefer EJ, Wolfe ML. Effects of an inhibitor of cholesteryl ester transfer protein on HDL cholesterol. N Engl J Med 2004;350,1505-15.

63. Funder JW. The off-target effects of torcetrapib. Endocrinol 2009; 150:2024-6.

64. Stein EA, Stroes ESG, Steiner G, et al. Safety and tolerability of dalcetrapib. Am J Cardiol 2009;104:82-91.

65. Freel EM, Connel JMC. Mechanism of hypertension: the expanding role of aldosterone. J Am Soc Nephrol 2004;15: 1993-2001. 